\title{
The Practice of Teachers' Written Corrective Feedback as Perceived by EFL Teachers and Supervisors
}

\author{
Fatma Mohamed Al Kharusi ${ }^{1} \&$ Abdo Mohammed Al-Mekhlafi ${ }^{1}$ \\ ${ }^{1}$ Associate professor, Sultan Qaboos University \\ Correspondence: Abdo Mohammed Al-Mekhlafi, Associate professor, Sultan Qaboos University, Oman. E-mail: \\ raymoh123321@gmail.com
}

Received: September 11, 2019

Accepted: October 8, 2019

Online Published: October 14, 2019

doi:10.5430/ijhe.v8n6p120

URL: https://doi.org/10.5430/ijhe.v8n6p120

\begin{abstract}
This study investigates EFL Post-Basic education teachers' and EFL supervisors' perceptions toward the importance of providing WCF and the practice of WCF including the techniques, focus, and follow-up methods. It attempts to examine the differences between teachers' and supervisors' perceptions on teachers' WCF practices. The data was collected from 156 EFL teachers who were teaching Post-Basic education grades (11-12) and 62 EFL supervisors through using an online questionnaire. The two participant groups (teachers and supervisors) were randomly selected from three governorates in Oman: Muscat, Al Batinah South, and Sharqia North. The study findings reveal that both teachers and supervisors valued the importance of providing WCF on writing errors. The researcher found that EFL Post Basic education teachers commonly used unfocused indirect coded WCF technique. They mainly focused on forms, particularly the grammatical errors. It was also found that they often used one-draft approach after providing WCF. The supervisors' responses showed that they had similar views on these practices. Thus, there were no statistically significant differences between the perceptions of the two groups regarding teachers' WCF practices.
\end{abstract}

Keywords: written corrective feedback (WCF), direct WCF, indirect WCF, focused WCF, unfocused WCF, follow-up methods

\section{Introduction}

Errors are inevitable in the language learning process. Writing errors could provide teachers with a general indication of students' writing performance and their level of competency in this complex productive skill (Atmaca, 2016). Moradian, Miri, and Hossein Nasab (2017) have stated that "one manifestation of written modality which can stimulate language learners to employ language to construct knowledge about language itself is written corrective feedback (WCF)" (p. 407). In other words, WCF, also known as error correction, is one of the strategies that plays a major role in improving students' writing skills (Ferris, 2006; Bitchener \& Knoch, 2009). It is well known that learners need to be corrected and guided because, unlike native speakers, foreign and second language learners cannot correct their own written errors merely from reading their writing aloud. Therefore, teacher intervention in the form of effective written corrective feedback (WCF) is necessary to overcome the writing problems encountered by L2 learners (Ferris, 2002; Goldstein, 2005, cited in Eissa \& Fares, 2010).

In Oman, it has been noted that although post-basic grade students have been learning English for about ten years, they still struggle to produce well-written texts (Al Seyabi and Tuzlukova, 2014). Teachers' written corrective feedback (WCF), if provided properly and effectively, can help students write more accurately and fluently (Ferris, 1999; Hyland, 2003; Bitchener, 2008; Srichanyachon, 2012). Although numerous studies have examined the effectiveness of error correction feedback in developing writing skills and investigating teachers' perceptions on WCF, few studies have investigated the use of written corrective feedback in Oman (Al-Said, 1996; Al Shabibi, 2008; Al-Hajri \& Al-Mahrooqi, 2014; Hubais \& Dumanig, 2014; Al Ajmi, 2015; Al-Bakri, 2015; Abdelraheem \& Fyle, 2016).

As a result, investigating the nature of teachers' WCF practices and the way in which they should be implemented is crucial in order to detect the importance of WCF in facilitating L2 development in writing (Bitchener, 2008). Although teachers are chiefly responsible for correcting their students' writing to help them improve it (Hyland \& Hyland, 2006; Knoch, 2011), and to the best of the author's knowledge, no studies to date have systematically explored Post-Basic education teachers' practices regarding WCF as viewed by two groups of practitioners: teachers 
and supervisors in Oman, it is crucial to investigate the perceptions teachers and supervisors on the Practice of Teachers' Written Corrective Feedback . This study, therefore, examines teachers' views of WCF. It also explores the perceptions of senior teachers and supervisors towards the practices used by teachers when giving WCF.

\section{Literature Review}

Feedback in writing is defined as an input that the writer receives from readers in the form of information that helps the writer revise and improve the written text. This information can be provided in several ways, such as comments, questions and suggestions (Keh, 1990 as cited in Wen, 2013). Feedback is one of the contributions to second language acquisition. Two main divisions are used to inform feedback in language learning: positive and negative. Negative feedback is an indication of learners' linguistic deficiencies. It is known as corrective feedback (CF) (Ellis, 2009). Baleghizadeh and Rezaei (2010) define 'corrective feedback' as "responses" to learner' errors of the produced utterances. These responses can be provided either orally or in written form. According to Bitchener and Storch (2016), written corrective feedback (WCF) is defined as "a written response to a linguistic error that has been made in the writing of a text by a L2 learner. It seeks to either correct the inaccurate usage or provide information about where the error has occurred and/or about the cause of the error and how it may be corrected" (p.1). To summarize the main points in their definition, the responses may consist of three main repairs of writing errors: indicating the error, introducing the correct form, and providing a metalinguistic explanation about the error. Teachers can use more than one repair when responding to their students' writing (Ellis, Loewen, \& Erlam, 2005).

\subsection{The Importance of WCF}

This section has discussed the argument about the use of WCF and its effective role in developing students' ability to improve their writing based on two leading theoretical perspectives: cognitive and sociocultural.

\subsubsection{Cognitive Perspective on WCF}

Researchers have examined a range of issues regarding cognitive information processing when learners are provided with written corrective feedback. These studies aimed to understand these cognitive processes and how they play a role in facilitating L2 development. They also aimed to investigate how cognitive processes may contribute to the development of students' writing competency in the long term. It is generally accepted that there are two types of linguistic knowledge: explicit and implicit knowledge. With explicit knowledge, learners need to consciously attend to the linguistic features, while implicit knowledge does not require learners to be aware of the language since it is used automatically. It is debatable whether explicit knowledge could be transformed to implicit knowledge through considerable practice of using the target language. Krashen (1985) argued that the conversion from explicit to implicit knowledge is not possible, while some interactionists confirmed the possibility of this conversion, since students can use the language automatically after paying conscious attention by doing ample practice (for example DeKeyser, 1993; Ellis, 2005). Providing written, rather than oral, feedback has two vital advantages for students: 1. "the permanence of time" and 2. "the additional time that learners have to think about what and how they write" (Bitchener \& Storch, 2016, p.11). These advantages may help student writers devote considerable time to noticing and being aware of the explicit knowledge received from WCF provided by their teachers. Through practice, this knowledge will be converted to implicit knowledge when students internalize the linguistic information provided in the form of written feedback. However, the question that first comes to mind is how this process might occur. This can be explained with regard to two models related to skill acquisition theories: Anderson's model and McLaughlin's information processing model.

Skill acquisition theories are mainly concerned with the progression from the conscious process of dealing with linguistic input to a less-controlled (automatic) process in which learners reach the procedural stage. With regard to Anderson's model, Anderson (1976, 1983, 1993) pointed out that this conversion process goes through three stages, starting from "declarative", moving to the "associative" stage, and ending up with the "autonomous" stage (as cited in Bitchener and Storch, 2016, p.13). Learners cannot move from one stage to another without practice. However, DeKeyser (1998) noted that learners should practice effectively through contextualized activities, as such contextual practice helps proceduralize the declarative knowledge and store it in the long-term memory. With regard to the second model, McLaughlin $(1978,1980,1987,1990)$ theorized the limitation of learners' capacity to process a large amount of information. They begin by devoting considerable cognitive effort to processing the information received from the written $\mathrm{CF}$ in their working memory, which is termed "controlled processing". Then, after repeating activities (practice), the process is likely to become more ingrained. The information will thus be stored in the long-term memory as units that can easily be retrieved when needed. In the long-term memory, the two types of knowledge (explicit and implicit knowledge) are stored by the process of comparison between existing knowledge 
(such as students' writing output) and new knowledge (such as WCF provided by the teachers to the learners) (as discussed in Bitchener \& Storch, 2016).

\subsubsection{Sociocultural Perspective on WCF}

A bulk number of studies have explained the findings of the effectiveness of WCF based on sociocultural theory (SCT) and other theories derived from this theoretical paradigm (for example activity theory (AT)). One of the main constructs in SCT that is strongly related to the issue of WCF and used to interpret how and why effective WCF facilitates L2 development is the Zone of Proximal Development (ZPD)_ scaffolding. According to Hyland (2003), WCF can "provide students with a sense of audience and sensitize them to the needs of readers [and] offers an additional layer of scaffolding to extend writing skills, promote accuracy and clear ideas, and develop an understanding of written genres" (p. 207). From an SCT perspective, the interaction between the expert (the teacher who provides WCF) and the novice (the student who receives WCF on his/her writing) is crucial in order to make progress in the development of accuracy in students' writing performance. Development occurs if teachers provide students with effective assistance. To make the assistance effective, teachers should consider the students' current level of development and provide help that is above their actual capacities (ZPD). Vygotsky (1978) defined ZPD as "the distance between the actual developmental level as determined by independent problem solving and the level of potential development as determined through problem solving under adult guidance or in collaboration with more capable peers" (p. 86). Lindqvist (2012) stated that scaffolding, the term that is relevant to the ZPD, helps less competent people (learners) perform the required task by receiving assistance from more competent people (teachers). Scaffolding is gradually reduced and finally removed when students reach the potential level of development and are able to complete the task successfully. Regarding WCF from an SCT perspective, no one single type or technique of WCF is most effective, because the WCF practices need to be attuned to students' ZPD. Since students' current levels of performance vary, teachers need to provide suitable WCF to each student depending on their ability to engage with the assistance (feedback) provided. Over time, students will move from being other-regulated to self-regulated and should be able to self-correct their own errors (Bitchener and Storch, 2016).

\subsection{Types of $W C F$}

The issue of how teachers provide corrective feedback and to what extent they are effective has become a significant research topic that has received a considerable amount of attention from both researchers and language teachers. Ellis (2008) categorized WCF into six types (direct, indirect, focused and un-focused CF, metalinguistic CF, electronic feedback, and reformulation). However, most research and methodology has examined the first three types, and only these are presented in this section since they are of most relevance to the current study.

\subsubsection{Direct and Indirect WCF}

Even though written corrective feedback, unlike oral feedback, is mainly explicit because any correction or words added to the student's piece of writing by the teacher constitutes error correction, its degree of explicitness ranges from more to less overt WCF. Thus, WCF can be divided into two types: direct (the correct form is supplied from the teacher to the learners) and indirect WCF (the errors are only indicated by the teachers and students are required to self-correct their own errors). These two types are thus mainly distinguished in terms of the degree of students' and teachers' involvement in the process of correction (Van Beuningen, 2010). Direct WCF comes in different forms, including "the crossing out of an unnecessary word/phrase/morpheme, the insertion of a missing word/phrase/morpheme, and the provision of the correct form or structure" (Bitchener \& Knoch, 2010, p. 209). In indirect WCF, errors are only shown by underlining or circling the incorrect form, indicated in the margin only; the type of error is specified using an error code.

The question "Which type of WCF is most effective?" has received much attention from L2 researchers and theorists. A range of studies have investigated the effectiveness of these types of feedback on developing the accuracy competence of L2 student writers. In the literature, most of these studies compare between direct and indirect WCF.

The studies by Frantzen (1995) and Robb, Ross, and Shortreed (1986) are examples of empirical studies that found no significant differences in the development of students' writing accuracy between the direct and indirect WCF groups. However, in her study of 20 intermediate ESL learners, Chandler (2003) reported that "direct correction and simple underlining of errors are significantly superior to describing the type of error (error codes), even with underlining, for reducing long-term error" (p. 267). She also asserted that direct error correction was the best method and had a considerable impact on students' writing accuracy. However, the major source of unreliability of this study is that the same participants received these forms of feedback consecutively instead of one particular form only. Van Beuningen, De Jong, and Kuiken (2008) pointed out that both direct and indirect WCF showed significant short-term 
effects on L2 development, whereas the impact of direct error correction was retained over time. Thus, the researchers concluded that direct feedback has more long-term effects than indirect feedback. This is in a complete agreement with the findings of Bitchener and Knoch (2010). In the latter study, although direct and indirect error correction was found to have a positive impact on the accurate use of English articles (for a one-week period), after ten weeks, the impact of direct WCF was retained. Nevertheless, a number of studies have found that indirect WCF is more effective than direct WCF because of its effectiveness in developing learners' engagement in correcting their own errors, enhancing problem-solving skills, and improving learners' ability to reflect on linguistic forms (Lalande, 1982; Lee, 1997; Ferris \& Roberts, 2001).

Thus, based on these inconsistent and conflicting findings of different empirical studies, it would be difficult to draw any firm conclusion with regard to the effectiveness of each type of WCF, and further studies are therefore needed.

\subsubsection{Focused and Unfocused WCF}

Written corrective feedback can also be provided in an extensive or intensive way. For example, teachers can either correct all or most of the students' errors (unfocused or comprehensive WCF) or select a few specific types of errors to correct at a time (focused or selective WCF). As Ellis (2009) noted, "processing corrections is likely to be more difficult in unfocused CF as the learner is required to attend to a variety of errors and thus is unlikely to be able to reflect much on each error" (p. 102). Thus, focused or selective WCF is more effective, as students are required to focus only on one error until they understand the nature of that error and can acquire the correct form accordingly. Theoretically, as discussed before, students may have difficulties with processing too much information from the feedback provided. In particular, students with a low level of L2 proficiency might need a higher level of cognitive load capacity to process the new information (WCF provided by the teacher). They also need to compare it to the existing information stored in their long-term memory and to operationalize the adapted knowledge. On the other hand, students with a high level of L2 proficiency (advanced learners) are capable of incorporating and internalizing the WCF input (Bitchener \& Storch, 2016).

A vast amount of research has been carried out to identify the impacts of unfocused (Van Beuningen et al., 2008, 2012) and focused feedback (for example Bitchener, 2008; Bitchener \& Knoch, 2008, 2009, 2010; Stefanou, 2014) on developing students' writing performance. However, it would not be possible to draw accurate findings if each approach were investigated separately. Thus, the studies that compared focused and unfocused feedback might be of more value in validating the effectiveness of each type of feedback and its efficient role in L2 accuracy development. In a study of 49 male Japanese intermediate EFL university students, Ellis, Sheen, Murakami, and Takashima (2008) investigated whether the focused approach is more effective than the unfocused one. In the focused group, students were provided with direct error correction on English articles, while the unfocused group were provided with WCF on English articles as well as all error categories. It was found that the two groups outperformed the control group (no feedback provided) but were equally effective. However, a study by Sheen, Wright and Moldawa (2009) of 80 ESL learners found that unfocused WCF was less effective than focused WCF in one grammatical category (English articles) and four grammatical categories (articles, copula 'be', regular and irregular past tense, and prepositions). Unlike Ellis et al. (2008), this result demonstrated a greater effectiveness of the selective approach of providing WCF compared to the comprehensive approach. However, one limitation of this research, as the researchers admitted, was the lack of consistency in providing comprehensive WCF, as some errors were corrected while others were ignored. The findings of the experimental study by Sheen et al. (2009) confirmed those of Farrokhi (2012), who investigated 60 advanced L2 learners. The focused WCF group outperformed the unfocused group in terms of using English articles accurately.

\subsection{The Focus of WCF}

As feedback providers differ in their way of providing WCF, they also vary in their focus on particular types of errors when making corrections. According to Burt (1975), teachers need to focus mainly on global errors, which are related to the organization of sentences, ideas, and paragraphs, rather than local ones, which may only affect a single element within a sentence. Burt differentiated between global and local errors in terms of the issue of communication. He has noted that global errors could cause communication problems, and Hendrickson (1978) has suggested that error correctors should pay more attention to providing feedback on this particular type of error to avoid any obstruction in communication with readers. Although Krashen denied the effectiveness of providing WCF in facilitating L2 acquisition, he has argued that CF could have the potential advantage of helping learners monitor their written language production. Krashen (1982) asserted that this beneficial effect of WCF could be gained when focusing on correcting "simple and portable" categories of grammatical features. However, there are many doubts about Krashen's argument. For example, Ellis (2009) argued that the absence of a theoretical basis of how to decide 
which errors are simple and portable might lead to inconsistency in error correction. Ferris (1999) also categorized these errors into two types: treatable and untreatable errors. She distinguished between these two types according to whether the grammatical feature is rule-based (treatable) or item-based (untreatable). If the feature has no specific rule that can be applied, it would be difficult for learners to self-correct their own errors by themselves, as they might need teachers' assistance in the form of explicit WCF (direct WCF). "Missing words, unnecessary words, and word order problems" are examples of untreatable errors (p.6). However, as treatable errors are governed by specific rules, learners find it easier to self-correct their own errors when they receive less explicit feedback (for example indirect WCF). "Subject-verb agreement, run-ons and comma splices, missing articles, verb form errors" are examples of treatable errors (p.6). However, Ellis' (2009) dichotomy has also been criticized. Thus, Van Beuningen (2010) suggested another category of error type, namely "grammatical errors" and "non-grammatical errors". He claimed that grammatical errors (such as syntactic errors) could be corrected by providing direct WCF, while indirect WCF is the best methodology to deal with non-grammatical errors (such as spelling and punctuation errors).

Despite the variation in the taxonomy of error types, in this study, the focus of WCF is oriented towards what Hyland (2003) suggested, since she asserted that teachers should provide WCF with considerable emphasis on the three main aspects of writing: organization, content, and language. However, focusing on language is the most commonly discussed aspect by L2 researchers, widely used by teachers, and mostly preferred by students (Van Beuningen, 2010). Language errors are divided into three categories: 1. grammar, including syntactic and morphological errors; 2. language expressions, including lexical errors; and 3. mechanics, including spelling, punctuation, and capitalization (Storch \& Tapper, 2000, as discussed in Al Shahrani \& Storch, 2014).

\subsection{Teachers' Perceptions and Practice of WCF}

Until now, teachers have held inconsistent views regarding the issues related to the process of responding to students' writing errors. According to Phipps and Borg (2009) "beliefs influence practices and practices can also lead to changes in beliefs" (p. 381). Teachers' WCF practices could be influenced by their beliefs about the significance of correcting students' writing errors to help students write accurately. On the basis of the viewpoint advocated by Lee (2009) that "uncovering the beliefs that underlie teachers' practices can help identify the factors that contribute to effective feedback" (p.14), a number of studies have addressed teachers' perceptions and practices regarding the provision of WCF. Lee (2003) examined the perceptions and practices of 206 secondary EFL Hong Kong teachers as well as the problems they encountered regarding giving feedback. The results showed that the majority of teachers used comprehensive WCF, while the teachers who were interviewed claimed that they preferred a selective approach in providing WCF. In addition, indirect WCF was preferred by grade 10-11 teachers, while direct WCF was mostly preferred by those who were teaching the lower grades (7-9). However, the majority of teachers (87\%) used indirect correction through error codes. It was also found that hinting at the location of errors, as well as hinting at the location of errors and categorizing them, were the least preferred and used strategies of correcting errors. Lee (2008) examined the WCF practices provided by 26 Hong Kong secondary English teachers through an analysis of 174 student texts marked by those teachers. The findings revealed that direct WCF was the predominant strategy used in correcting students' writing ( $71.5 \%$ of error feedback points were corrected using direct WCF), followed by using coded feedback $(21.6 \%)$. The majority of the respondents $(94.1 \%)$ mainly focused on language errors, although teachers asserted in the interviews that they were in favour of focusing on other aspects of writing. Lee (2009) published a subsequent paper concerning 10 mismatches between teachers' practices and perceptions from the two studies described above (Lee, 2003, 2008), as the former study investigated teachers' perceptions of WCF, while the latter focused on teachers' practices of WCF in reality. Some of these discrepancies are related to the type, amount, and focus of WCF provided. For example, teachers preferred indirect selective WCF but used direct comprehensive WCF in actual practice. In addition, they appreciated the importance of focusing on all aspects of writing (language, content and organization), while they primarily tended to provide feedback on linguistic errors in practice. Another study by Montgomery and Baker (2007) had the same aim of investigating the alignment between teachers' perceptions and actual feedback by comparing the results of the survey to the teachers' actual WCF practices. The researchers found that although teachers (13 writing instructors) thought that they provided more WCF on global errors (for example content and organization), local errors (for example grammar and mechanics) ranked as the most common type of error they focused on in actual practice; global issues received less attention.

The purpose of the study was examining teachers and supervisors perceptions on EFL teachers' practice of written corrective feedback. The research questions that this study seeks to answer are as follows:

1. What perceptions do EFL teachers have of their practice of WCF? 
2. What perceptions do EFL supervisors have of teachers' practice of WCF?

3. Are there any significant differences between EFL teachers' and supervisors' perceptions of WCF?

\section{Methodology}

\subsection{Research Design}

As the aim of the present study was to explore EFL teachers' and supervisors' views on teachers' WCF practices, it was considered to have the nature of descriptive research. This descriptive study did not aim to answer questions about how, when, and why teachers use particular types of WCF practices, as it mainly focuses on "what" WCF practices are used by EFL teachers. The quantitative data of this study was obtained from the questionnaires. The necessary approval of this study was obtained from the Ministry of Education (MOE).

\subsection{Population and Sample}

The population of the present study includes all English language teachers (both male and female) who are teaching Post-Basic grades (11-12) in public schools in three governorates in Oman (Muscat, Al-Batinah South, and Sharqia North) during the academic year 2017/2018. It also includes all the supervisors of the English language subject and all English language senior teachers in the schools that include grades 11-12 from the three mentioned governorates. These particular governorates were chosen because they are fairly representative of the cultural and educational diversity in Oman. Based on the statistics given by the Ministry of Education (MOE), there are about 541 grade 11-12 EFL teachers in these three governorates (258 males and 283 females), while the number of supervisors (senior teachers and regional supervisors) is 66 . The present study includes two groups of participants: EFL teachers and supervisors.

\subsubsection{EFL Teachers}

About $30 \%$ of the teacher population was randomly selected from these three regions using simple random selection technique. Having a $100 \%$ response rate, about 156 grade-11-12 EFL teachers participated in this study. The sample included 46 male teachers $(29.5 \%)$ and 110 female teachers (70.5\%). The sample also involved 71 participants who were from Muscat (16 males and 55 females), 55 from Al-Batinah South (21 males and 34 females) and 30 teachers from Sharqia North ( 9 males and 21 females).

\subsubsection{EFL Supervisors}

Almost all the supervisor participants were included. A total of 62 of them took part in this study, of whom 16 were male (25.8\%) and 46 females (74.2\%). The sample of supervisor participants contains 45 senior teachers and 17 regional supervisors. The numbers of supervisors distributed in Muscat, Al-Batinah South and Sharqia North were 21, 29, 12 respectively. There were 48 supervisors who had obtained a Bachelor's degree (77.4\%) and 14 supervisors who had a Master's degree (22.6\%).

\subsection{Research Instrument}

The instruments used to collect the research data were a 5-point Likert scale online-questionnaires administered using Google Forms. In fact, the researcher chose the questionnaire as the research instrument in this study because it served the purpose of collecting data in a short period of time from a large number of randomly selected Post-Basic EFL teachers and EFL supervisors about their perceptions on issues related to WCF.

In this study, the questionnaires were used to answer all the three research questions. The researcher developed the questionnaire items from similar questionnaires used by other researchers in previous studies (Lee, 2003; Ko, 2010; Eissa \& Fares, 2010; Al Hajri \& Al-Mahrooqi, 2013; Al Shamsi, 2013). Some items were modified and some new items were added to target all the issues investigated in this study.

Two questionnaires were used. The first one was for EFL teacher participants teaching Post-Basic grades (11-12) in the academic year 2017/2018, and the second questionnaire was for supervisor participants in three regions in Oman (Muscat, Al-Batinah South and Sharqia North). The items on the two questionnaires are almost identical. However, there was a slight difference between them which is that different wording was used depending on the target group of participants. For example, the teachers were required to self-assess their own WCF practices, while supervisors were asked about their perceptions of teachers' practices when using WCF. Both questionnaires' responses were provided anonymously.

\subsubsection{Validity and Reliability of the Questionnaires}

To check the validity of the research instruments, the questionnaires were reviewed by a panel of area experts and 
practitioners. With regard to reliability, the questionnaires were piloted with 20 teachers and 10 supervisors who were selected randomly from the Al Batinah North governorate. The Cronbach's Alpha coefficient of the supervisors' questionnaire was .89 , while the Cronbach's Alpha of teachers' questionnaire was approximately .83 .

\section{Results and Discussion}

The results pertaining to each question are presented in details below.

\section{Q1. What Perceptions Do EFL Teachers Have of their Practice of WCF?}

The answer to this question is based on an analysis of the data gathered by the teachers' questionnaire. Table 1 shows the scale values used to interpret the means $(M)$ of the level of agreement with the importance of providing WCF and the level of practicing WCF.

Table 1. Scale Used to Interpret the Means of EFL Teachers' Perceptions of the Importance of Providing WCF and practicing WCF

\begin{tabular}{ccc}
\hline Scale Value & Level of agreement (Section 2) & Level of Practice (Section 3) \\
\hline $1-1.79$ & Very low agreement & Not practiced \\
$1.8-2.59$ & Low agreement & Less practiced \\
$2.6-3.39$ & Moderate agreement & Moderately practiced \\
$3.4-4.19$ & High agreement & Well practiced \\
$4.2-5$ & Very high agreement & Highly practiced \\
\hline
\end{tabular}

\subsection{EFL Teachers' Perceptions of the Importance of Providing WCF}

The participants were provided with 12 statements on the importance of providing WCF and were asked to indicate to what extent they agreed or disagreed with each statement. The means and standard deviations of each statement are demonstrated in Table 2.

Table 2. Means and Standard Deviations of EFL Teachers' Perceptions of the Importance of Providing WCF $(\mathrm{N}=$ 156)

\begin{tabular}{cccc}
\hline NO. & Statements & $M$ & $S D$ \\
\hline 1 & It is important to provide WCF on student errors in writing. & 4.69 & .46 \\
2 & Teachers' WCF helps students improve their overall writing performance. & 4.61 & .54 \\
3 & Providing WFC helps students notice their errors. & 4.47 & .63 \\
4 & Providing WCF gives students the chance to correct their errors. & 4.46 & .59 \\
5 & Providing WCF promotes self-learning. & 4.35 & .67 \\
6 & Providing WCF raises students' awareness of the nature of errors. & 4.33 & .60 \\
7 & Providing WCF prepares students for higher levels of academic writing. & 4.32 & .66 \\
8 & Providing WCF reduces the repetition of the same error. & 4.28 & .77 \\
9 & Providing WCF helps students reflect on their writing. & 4.23 & .72 \\
10 & Providing WCF helps students meet the Ministry of Education's standards. & 3.98 & .74 \\
11 & Students pay attention to their teachers' WFC. & 3.94 & .86 \\
12 & Students can improve their writing without teachers' WCF. & 2.66 & 1.02 \\
\hline Total & & $\mathbf{4 . 1 9}$ & $\mathbf{. 4 1}$ \\
\hline
\end{tabular}

As shown in Table 2, the mean scores range from 4.69 to 2.66. The first statement has the highest mean score (4.69) which indicates that teachers are fully aware of the need to provide WCF and are very much in agreement with providing WCF on students' writing errors. Also, they strongly agree that teachers' WCF helps to improve the students' overall writing performance (4.61). This result is in contradiction with Truscott (1996) who argued against the benefits of WCF for L2 development. However, several previous studies confirm this result which substantiates the importance of providing WCF on students' writings and its significant role in improving their writing performance (Alkhatib, 2015; Ghani \& Ahmad, 2016; Rajab et al. 2016; Thao \& Anh, 2017). The lowest mean score indicates that the teachers' responses show that they are undecided on whether students are able to improve their writing without teachers' WCF (2.66). In Al Hajri and Al-Mahrooqi's (2013) study, the student participants show moderate agreement with this statement indicating that the students are also unsure whether they would be able to correct their writing errors without teachers' feedback. Statement 11 demonstrates that teachers are also unsure if 
their students pay attention to their written corrective feedback. This result does not match with the result obtained by Al Hajri and Al-Mahrooqi (2013) as the results of this study indicate that the students pay a great deal of attention to their teachers' WCF $(M=4.22)$. Statements 3, 4, and 8 aim to elicit the teachers' perceptions of the short-term effects of WCF. Statement 8 gains the lowest mean score when compared to Statements 3 and 4, which indicates that teachers believe that WCF helps learners notice and correct their errors more than it decreases the chance of the learners repeating the same errors over time. One possible interpretation could refer to the lack of practice because teachers rarely used multiple drafts approach after providing WCF. So, referring to the cognitive perspective on WCF, the lack of practice hinders the process of transferring the explicit knowledge to implicit knowledge and students may fail to compare their actual output (written text) with the information from the WCF provided by the teacher. Statements 5, 6, 7, 9, and 10 are related to the long-term effects of WCF. The responses show that they strongly agree that providing students with WCF helps promote self-learning (4.35), raise students' awareness of the nature of errors (4.33), prepare them for higher levels of academic writing (e.g. the level of writing performance required for university) (4.32) and reflect upon their writing (4.23). Teachers agree that providing WCF helps students meet the Ministry of Education (MOE)'s standards (3.98).

Another important point to discuss was raised by two of the respondents who commented, in the space provided after this section in the teachers' questionnaire, that the benefits of WCF cannot be generalised to all students and teachers as a number of variables need to be taken into consideration. For example, as one of them stated, "it depends on the quality and level of the feedback. It also depends on whether students are trained to read the feedback and act upon its recommendations". The teacher's opinion supports the findings of Eissa and Fares (2010) as the teachers had positive attitudes towards the importance of training students how to correct and deal with their own errors. This teacher also thinks that EFL teachers could train students on how to incorporate teachers' feedback by using the drafting approach. This approach helps students to do ample practice which in turn helps them internalize and incorporate the received feedback.

\subsection{EFL Teachers' Perceptions of their WCF Practices:}

\subsubsection{The Techniques of WCF}

The respondents were asked to assess how frequently they used different WCF techniques. They were presented with 13 items. Table 3 presents the means and standard deviations of each item. The items below are ordered from the highest to the lowest mean scores.

Table 3. Means and Standard Deviations of EFL Teachers' Perceptions of the Techniques of WCF they Provide in Relation to their Students' Writing Errors $(\mathrm{N}=156)$

\begin{tabular}{|c|c|c|c|}
\hline NO. & Statements & $M$ & $S D$ \\
\hline 1 & Providing WCF on all types of students' errors in writing. & 4.05 & 1.01 \\
\hline 2 & $\begin{array}{l}\text { Indicating (underlining/circling) errors and categorising them (with the help of a } \\
\text { marking code), but without correcting them. }\end{array}$ & 3.89 & 1.11 \\
\hline 3 & Providing WCF on the errors that are related to students' specific needs. & 3.80 & 0.99 \\
\hline 4 & Indicating (underlining/circling) errors and correcting them. & 3.78 & 1.11 \\
\hline 5 & $\begin{array}{l}\text { Indicating (underlining/circling) errors, correcting them and categorising them (with } \\
\text { the help of a marking code). }\end{array}$ & 3.74 & 1.22 \\
\hline 6 & Deciding what errors to provide feedback on while marking. & 3.71 & 1.08 \\
\hline 7 & $\begin{array}{l}\text { Hinting at the location of errors and categorising them (with the help of a marking } \\
\text { code), e.g. by writing 'Prep' in the margin to indicate a preposition error on a specific } \\
\text { line. }\end{array}$ & 3.61 & 1.32 \\
\hline 8 & Indicating (underlining/circling) errors, but without correcting them. & 3.57 & 1.15 \\
\hline 9 & Providing the same type of feedback to all students. & 3.44 & 1.26 \\
\hline 10 & Using a shorthand checklist when providing WCF on students' writing. & 3.43 & 1.21 \\
\hline 11 & $\begin{array}{c}\text { Hinting at the location of errors, e.g., by putting a mark in the margin to indicate an } \\
\text { error on a specific line. }\end{array}$ & 3.38 & 1.31 \\
\hline 12 & $\begin{array}{c}\text { Organising peer WCF to give students the opportunity to provide feedback on each } \\
\text { other's writing. }\end{array}$ & 3.37 & 1.14 \\
\hline 13 & Providing WCF on one type of error at a time. & 3.11 & 1.24 \\
\hline Total & & 3.61 & .66 \\
\hline
\end{tabular}


The results in the table above show that unfocused WCF through providing WCF on all types of students' writing errors rank as the most practiced techniques by the teachers (4.05). One reason behind using this technique could be related to the belief that they are responsible for giving feedback on all the students' writing errors and that their students completely rely on them to correct their errors. One more reason could be that the students prefer to receive comprehensive WCF from their teachers. The second most practiced technique ranked after providing unfocused WCF is indirect coded WCF technique (3.89). It is shown that EFL teachers often indicate errors and categorise them with the help of a marking code, but without correcting them. This is in agreement with the results obtained by Lee (2003) as Grade 10-11 teachers also prefer indirect coded feedback. This result is also in line with the discussion raised by Ferris, Liu, Sinha, and Senna (2012) who points out that "explicit CF with specific terms or other metalinguistic information may, for some students, be more valuable than unlabelled (implicit) one" (p. 3, as cited in Erkkilä, 2013, p. 10). This is also confirmed the results of the two techniques of indirect WCF: hinting at the location of errors and categorising them (using marking code) and hinting at the location of errors (without using marking code). The former technique gains higher mean score compared to the later technique. This demonstrates that teachers commonly practice explicit WCF techniques in responding to their students' errors in writing. The lowest mean score goes for the technique of providing WCF on one type of error at a time (3.11). Thus, focused WCF are moderately practiced by the teachers. This result is in contrast with Al-Said's (1996) findings as the teachers, in her study, preferred focusing on specific types of errors rather than providing full corrections. The teachers are also asked about how often they organise peer WCF to give students the opportunity to provide feedback on one another's writing and the mean score indicates that they moderately practice this technique (3.37). The reason could be inferred from the results obtained by Al-Said (1996). It was found that teachers believed that teachers' WCF is more helpful than peer WCF because teachers are more qualified to give correct feedback effectively while peers could not be relied upon to provide good feedback. Hinting at the location of errors technique is also moderately practiced by the EFL teacher participants (3.38). The possible reason could be due to the fact that the students commonly find it to be too demanding, as they are required to locate, indicate and correct their errors by themselves.

\subsubsection{The Focus of WCF}

This sub-section is divided into two parts. The first part concerns how often teachers focus on the three main aspects of writing (content, organisation, and language). The second part mainly focuses on the linguistic categories (grammar, vocabulary, and mechanics) that teachers focus on while providing WCF on language errors. The results are presented below in Table 4.

Table 4. Means and Standard Deviations of EFL Teachers' Perceptions of the Focus of WCF When Correcting Students' Writing $(\mathrm{N}=156)$

\begin{tabular}{cccc}
\hline NO. & Statements & & \\
\hline & When correcting students' writing, I focus on: & $M$ & $S D$ \\
1 & Language & 4.71 & .54 \\
2 & Content & 4.41 & .81 \\
3 & Organisation & 4.28 & .78 \\
\hline & Total & $\mathbf{4 . 4 7}$ & $\mathbf{. 5 7}$ \\
\hline & When responding to students' language errors, I focus on: & $M$ & $S D$ \\
1 & Grammar & 4.76 & .49 \\
3 & Mechanics (Spelling, punctuation, capitalization) & 4.57 & .68 \\
\hline Total & Vocabulary & 4.48 & .68 \\
\hline
\end{tabular}

Although the mean scores of the three aspects (4.47) indicate a very high level of practice, the highest mean relates to the language (4.71). This result illustrates that most of the teacher respondents focus on providing WCF on language. This finding is directly in line with the findings of previous studies (Lee, 2003; Montgomery and Baker, 2007; Hamouda', 2011; Amrhein and Nassaji, 2010; Al-Said, 1996; Al Shabibi, 2008). Organisation has the lowest mean score compared to the other two aspects of writing. A possible explanation of this finding could be that students generally prefer their teachers to focus on their linguistic errors rather than on content and organisation. This was revealed by Al Hajri and Al-Mahrooqi (2013) who also found that students tended to prefer to receive feedback on language errors. Another reason behind this result might be that teachers may have noticed that their students' 
most frequent errors were related to language, so they tended to provide WCF mainly on linguistic errors. In the second part, providing WCF on the three linguistic features (grammar, vocabulary, and mechanics) is highly practiced by the teachers. However, grammar is the most frequent linguistic category that is focused on by the participants, while the second most frequent linguistic category is mechanics. Focusing on providing WCF on vocabulary has the lowest mean score. The reason could be that it is easier for teachers to give feedback on grammar and mechanics as these are governed by specific rules that help teachers to quickly and easily identify the errors. Vocabulary, in contrast, is not related to a clear set of rules. This make it more demanding, not only for teachers to provide feedback on vocabulary, but also for students to understand it. Interestingly, this result is very similar to the results obtained by Hamouda (2011) regarding the focus of WCF. This agreement with Hamouda's (2011) results could be due to the similarities between the Omani and Saudi EFL contexts in terms of the educational system, the cultural factors, and the common concerns faced by Arab students in their writing.

\subsubsection{The Follow-up Methods}

Moving to the last sub-section, the respondents were required to assess their level of practice of different methods following the WCF. The means and standard deviations of each of the six items included in this sub-section are presented in Table 5. The items are ranked in order from the highest to the lowest mean scores.

Table 5. Means and Standard Deviations of EFL Teachers' Perceptions of the Follow-up Methods after Providing WCF $(\mathrm{N}=156)$

\begin{tabular}{cccc}
\hline NO. & Statements & $M$ & $S D$ \\
\hline 1 & Ask students to submit one draft after they review the feedback. & 3.94 & 1.07 \\
2 & Give more writing activities for students who have writing problems. & 3.79 & .94 \\
3 & Make students correct errors in classroom. & 3.60 & 1.12 \\
4 & Publish good writing work, e.g. in school magazines, social media websites and in & 3.14 & 1.16 \\
& class. & 3.11 & 1.21 \\
5 & Make students correct errors outside classroom. & 2.57 & 1.27 \\
6 & Ask students to submit multiple drafts after they review the feedback. & $\mathbf{3 . 3 6}$ & $\mathbf{. 7 0}$ \\
\hline Total & &
\end{tabular}

As illustrated in Table 5, the mean values range from 3.94 to 2.57 . The highest mean value indicates that asking students to submit one draft after teachers have provided written feedback on their original texts is the most practiced follow-up method used by the respondents. One reason of this result could be that teachers tend to ensure that their students noticed their errors, understood the received WCF on their errors, and corrected them. On the other hand, the lowest mean score indicates that teachers rarely ask their students to rewrite multiple drafts, possibly due to the constraints of time and class size. Teachers may not have time to spend on revising more than one draft as they are overloaded with school duties. Revising more than one draft would entail providing WCF on too many papers because of the high number of students in each class. This result supports previous findings in Al khatib (2015). It was found that none of the teachers in her study were practicing multiple-drafts approach although they believed in its importance to help students produce good writing. The mean score of Statement 2, which is related to the method used to deal with weak achievers in writing, indicates that the practice method, that is giving more writing activities to students who have writing problems, is well practiced by the teachers (3.79). However, in Al Shamsi (2013), the results show a medium use of this method by Grades 4-8 English teachers. The follow-up method used to deal with high achievers through publishing good students' writing work such as publishing in school magazines, social media websites or in class (Statement 4) is moderately practiced (3.14). The finding of this method does not support Al Shamsi (2013) as it was rarely used by the participants with the mean score being 2.26. One teacher participant of the current study added to this statement by saying that she sometimes lets the good writers read their texts out loud to the whole class as a sort of reward. The data gathered from Statements 3 and 5, which concerned when students are required to correct their own errors after they receive their teachers' WCF, shows that teachers usually ask their students to correct errors in class (3.60) while they sometime ask them to correct their errors outside classroom (3.11).

Q2. What Perceptions Do EFL Supervisors' Have of Teachers' Practice of WCF? 


\subsection{EFL Supervisors' Perceptions of the Importance of Providing WCF}

The respondents were presented with 12 statements to investigate their point of view on the significance of providing WCF on students' writing errors. The means and standard deviations relating to each statement are displayed in Table 6.

Table 6. Means and Standard Deviations of EFL Supervisors' Perceptions of the Importance of Providing Teachers' $\mathrm{WCF}(\mathrm{N}=62)$

\begin{tabular}{cccc}
\hline NO. & Statements & $M$ & $S D$ \\
\hline 1 & It is important to provide WCF on student errors in writing. & 4.75 & .43 \\
2 & Teachers' WCF helps students improve their overall writing performance. & 4.61 & .55 \\
3 & Providing WCF helps students notice their errors. & 4.50 & .62 \\
4 & Providing WCF prepares students for higher levels of academic writing. & 4.45 & .69 \\
5 & Providing WCF raises students' awareness of the nature of errors. & 4.40 & .61 \\
6 & Providing WCF gives students the chance to correct their errors. & 4.38 & .66 \\
7 & Providing WCF reduces repetition of the same error. & 4.20 & .81 \\
8 & Providing WCF helps students reflect on their writing. & 4.19 & .80 \\
9 & Providing WCF promotes self-learning. & 4.14 & .95 \\
10 & Providing WCF helps students meet the Ministry of Education's standards. & 3.90 & .88 \\
11 & Students pay attention to their teachers' WCF & 3.80 & .93 \\
12 & Students can improve their writing without teachers' WCF. & 3.54 & 1.03 \\
\hline Total & & $\mathbf{4 . 2 4}$ & $\mathbf{0 . 4 1}$ \\
\hline
\end{tabular}

Generally, the total mean of the EFL supervisors' perceptions of the importance of providing WCF is 4.24, which indicates that the supervisors are in a very high agreement regarding this issue. They generally perceive that teachers' WCF practices in terms of its techniques, focus, and follow-up methods are well practiced by the English language teachers (3.66).

The means range from 4.75 , which falls in the scale category of a very high level of agreement, to 3.54 , which indicates a high level of agreement. The highest mean score is linked to the first statement which indicates that supervisors strongly agreed that it is important to provide WCF, while the lowest mean value is 3.54 which indicates that supervisors are unsure if students can improve their writing without receiving teachers' WCF. This is similar to the results obtained regarding the EFL teachers' perceptions of the importance of WCF. The supervisors' view on the short-term development effects of WCF, as represented in the three statements (3, 6, and 7), is consistent with teachers' view. The supervisors strongly agree that WCF helps students notice their errors (4.50) and gives them a chance to correct such errors (4.38). They feel it has less impact on reducing the repetition of errors (4.20). The five statements $(4,5,8,9$, and 10) concern the long-term effects of WCF. Their mean values range from 3.90 to 4.45 . The highest mean score of these five statements is obtained in connection with Statement 4 . This result means that the respondents strongly agree with the effectiveness of WCF in preparing students for higher level of academic writing. However, the lowest mean value is 3.90 in connection with the Statement 10, which means that there is a high level of agreement on the impact of providing WCF on helping students meet the Ministry of Education's standards.

\subsection{EFL Supervisors' Perceptions of Teachers' WCF Practices}

This section set out to discover their perceptions of how often teachers use different types and techniques of WCF, how often they focus on content, organisation and language and how often teachers use different methods after providing WCF. Table 7 displays the grand means of the three subsections included in the second section of the supervisors' questionnaire. 
Table 7. Means and Standard Deviations of EFL Supervisors' Perceptions of Teachers' WCF Practices in Three Sub-Sections $(\mathrm{N}=62)$

\begin{tabular}{ccc}
\hline Sub-sections of Teachers' WCF Practices & $M$ & $S D$ \\
\hline A. The techniques of WCF & 3.51 & .69 \\
B. The focus of WCF & 4.37 & .41 \\
C. The follow-up methods & 3.27 & .78 \\
\hline Total & $\mathbf{3 . 6 6}$ & $\mathbf{0 . 5 4}$
\end{tabular}

The mean of sub-section A demonstrates that techniques of WCF are well practiced by the teachers $(M=3.51, S D$ $=.69$ ). The result of the second sub-section shows that the supervisors perceive that teachers always focus on the three aspects of writing $(M=4.37, S D=.41)$. The total mean scores of the last sub-section indicates that the follow-up methods after teachers provide WCF are moderately practiced by the teachers $(M=3.27, S D=.78)$. The key results obtained in each sub-section describe the supervisors' perceptions of these issues in more detail. The scale of the level of practice presented in Table 1 is used for interpreting the mean scores.

\subsubsection{The Techniques of WCF}

The EFL supervisor participants were presented with 13 statements to evaluate to what extent teachers practice different WCF techniques based on their own observation. The means and standard deviations of each statement are represented below in Table 8. The items are ordered according to the mean scores from highest to lowest.

Table 8. Means and Standard Deviations of EFL Supervisors' Perceptions of the Techniques of WCF Provided by Teachers to Students on their Errors in Writing $(\mathrm{N}=62)$

\begin{tabular}{|c|c|c|c|}
\hline$N O$. & Statements & $M$ & $S D$ \\
\hline 1 & $\begin{array}{l}\text { Indicating (underlining/circling) errors and categorising them (with the help of a } \\
\text { marking code), but without correcting them. }\end{array}$ & 3.80 & 1.00 \\
\hline 2 & Indicating (underlining/circling) errors and correcting them. & 3.72 & 1.05 \\
\hline 3 & Providing WCF on all types of students' writing errors. & 3.66 & 1.14 \\
\hline 4 & $\begin{array}{l}\text { Indicating (underlining/circling) errors, correcting them and categorising them (with } \\
\text { the help of a marking code). }\end{array}$ & 3.64 & 1.10 \\
\hline 5 & Indicating (underlining/circling) errors, but without correcting them. & 3.64 & 1.07 \\
\hline 6 & Deciding on what errors to provide feedback while marking. & 3.64 & 1.11 \\
\hline 7 & $\begin{array}{c}\text { Providing WCF on the errors that are related to students' specific needs. Providing } \\
\text { WCF on all types of students' writing errors }\end{array}$ & 3.59 & 1.13 \\
\hline 8 & $\begin{array}{l}\text { Hinting at the location of errors and categorising them (with the help of a marking } \\
\text { code), e.g. by writing 'Prep' in the margin to indicate a preposition error on a specific } \\
\text { line. }\end{array}$ & 3.58 & 1.30 \\
\hline 9 & Using a shorthand checklist when providing WCF on students' writing. & 3.45 & 1.27 \\
\hline 10 & Providing the same type of feedback to all students. & 3.37 & 1.23 \\
\hline 11 & $\begin{array}{c}\text { Hinting at the location of errors, e.g. by putting a mark in the margin to indicate an } \\
\text { error on a specific line. }\end{array}$ & 3.29 & 1.23 \\
\hline 12 & $\begin{array}{c}\text { Organising peer WCF to give students the opportunity to provide feedback on each } \\
\text { other's writing. }\end{array}$ & 3.29 & 1.04 \\
\hline 13 & Providing WCF on one type of error at a time. & 3.00 & 1.17 \\
\hline Total & & 3.51 & .69 \\
\hline
\end{tabular}

The mean scores of these items range from 3.80 to 3.00. When looking at the highest mean score of these statements (3.80), it is evident that the respondents think that EFL teachers often use indirect WCF by indicating (underlining /circling) errors and categorising them (with the help of a marking code), but without correcting them. The second highest mean value is connected to practicing direct feedback through indicating (underlining/circling) errors and directly correcting them. On the other hand, the lowest mean score indicates a moderate level of practice of the 
technique of focused WCF through providing WCF on one type of error at a time. However, the mean value of 3.66 (See Statement 3) indicates that supervisors perceive the unfocused WCF technique as it is well practiced by the EFL teachers. This matches with the EFL teachers' perceptions of their practice of this particular technique. The second lowest mean score is 3.29 which referred to the two WCF techniques: hinting at the location of errors by putting a mark in the margin to indicate an error on a specific line and organising peer WCF. This is considered to be a moderate practice level. That is, the supervisors believe that these techniques are only sometimes used by EFL teachers. Also, it is found that the techniques of indirect codded WCF, indirect un-coded WCF, and selecting errors on an ad hoc basis (See Statements 4, 5, and 6) have the same mean score (3.64) which indicates a well-practiced level. However, the supervisor' opinion on the use of indirect un-coded WCF technique (Statement 5) has less variation $(S D=1.07)$ compared to the other two techniques (Statements 4 and 6$)$.

\subsubsection{The Focus of WCF}

The results of the types of errors that teachers focus on when providing WCF as viewed by the supervisors are presented in Table 9.

Table 9. Means and Standard Deviations of EFL Supervisors' Perceptions of the Focus of WCF When Correcting Students' Writings $(\mathrm{N}=62)$

\begin{tabular}{cccc}
\hline$N O$. & Statements & & \\
\hline & When correcting students' writings, teachers focus on: & $M$ & $S D$ \\
1 & Language & 4.77 & .45 \\
2 & Content & 4.09 & .86 \\
3 & Organization & 3.98 & .89 \\
\hline & Total & $\mathbf{4 . 2 8}$ & $\mathbf{. 5 4}$ \\
\hline & When responding to students' language errors, teachers focus on: & $M$ & $S D$ \\
1 & Gechanics (spelling, punctuation, capitalisation) & 4.72 & .51 \\
2 & Vocabulary & 4.38 & .73 \\
\hline Total & & 4.29 & .63 \\
\hline
\end{tabular}

In the first part of this sub-section, the table shows that supervisors perceive teachers as they highly focus on the three main aspects of writing (4.28). When the mean scores are ordered from the highest to the lowest, it is evident that the supervisor respondents are of the belief that teachers always provide WCF on language errors, followed by focusing on content and organisation. Thus, there is considerable agreement in teachers' perceptions of their own focus on these three main aspects of writing. In the second part of this sub-section, supervisors, like the teachers themselves, perceive teachers as individuals who highly practice giving WCF on the three linguistic features: grammar, mechanics, and vocabulary (4.47). They think that the teachers always provide WCF on grammatical errors while they often provide WCF on the mechanics of writing such as spelling, punctuation and capitalisation. The lowest mean score is in connection with vocabulary. Again, the supervisor' perceptions of the focus of teachers' WCF align with the perceptions of the teachers themselves.

\subsubsection{The Follow-up Methods}

The mean and standard deviation values presented in Table 10 are interpreted to identify the perceptions of the methods used once the teachers have provided WCF as perceived by EFL supervisors. 
Table 10. Means and Standard Deviations of EFL Supervisors' Perceptions of the Follow-up Methods after Teachers Provide WCF $(\mathrm{N}=62)$

\begin{tabular}{cccc}
\hline NO. & Statements & $M$ & $S D$ \\
\hline 1 & Ask students to submit one draft after they review the feedback. & 3.85 & 1.14 \\
2 & Give more writing activities for students who have writing problems. & 3.63 & 1.07 \\
3 & Make students correct errors in classroom. & 3.32 & 1.25 \\
4 & Make students correct errors outside classroom. & 3.22 & 1.23 \\
5 & Publish good writing work, e.g. in school magazines, social media websites, in & 2.92 & 1.32 \\
& class. & 2.71 & 1.31 \\
\hline Total & Ask students to submit multiple drafts after they review the feedback. & $\mathbf{3 . 2 7}$ & $\mathbf{. 7 8}$ \\
\hline
\end{tabular}

The table above reveals that the highest mean score is 3.85 while the lowest is 2.71 . The former implies that asking students to write one draft after they have reviewed their teachers' feedback is the most practiced follow-up method. The latter mean score indicates that the supervisors perceive the method of using multiple drafts to be moderately practiced by the EFL teachers. This result indicates that supervisors perceive that EFL teachers often ask their students to review their WCF and write the correct version of produced text while they only sometimes ask their students to produce multiple drafts. The data regarding to Statements 3 and 4 , which are related to whether teachers ask students to correct the errors during or after class, indicates that the supervisors' perceptions regarding this issue matches with teachers' opinion. The supervisors also think that teachers sometimes tend to ask students to correct errors in class rather than after. The mean values of the Statements 2 and 5 show that the supervisors also believe that teachers more commonly set students with a low proficiency level in writing practice tasks while they sometimes publish the texts written by the better students.

Q3. Are there any Significant Differences between EFL Teachers' and Supervisors' Perceptions of WCF?

An independent-sample t-test was conducted to find out if there are any significant differences between EFL teachers' and supervisors' perceptions of WCF. The results are presented in Table 11.

Table 11. The Differences between EFL Teachers' and Supervisors' Perception of WCF (Independent Sample t-test)

\begin{tabular}{ccccccc}
\hline Groups & $N$ & $M$ & $S D$ & $T$ & $D f$ & Sig.(2-tailed) \\
\hline Supervisors & 62 & 3.85 & .44 & & & \\
Teachers & 156 & 3.91 & .39 & -0.947 & 216 & .345
\end{tabular}

As Table 11 shows, there are no statistically significant differences between EFL supervisors' perceptions and EFL teachers' perceptions, $t(216)=-0.947, p=.345$. This result provides evidence that teachers are actually practicing what they report in terms of WCF because the top-down perspective of their supervisors matches with the teachers' responses. Therefore, it appears that the teachers, who participated in this study, have truly reflected their actual WCF practice.

\section{Summary, Conclusion and Implications}

This study primarily aims to identify the perceptions of EFL teachers who are teaching Post-Basic grades and EFL supervisors about teachers' written corrective feedback practices including their attitude regarding the benefits of WCF, the techniques of WCF teachers are practicing, the aspects of writing they mainly focus on, and the follow-up methods they use after providing WCF. The study reveals that EFL Post-Basic teachers and supervisors have positive perceptions of the benefits of WCF. It is strongly suggested that it is important to provide WCF on students' writing errors and it helps to improve the students' writing performance overall. Also, it was clear that all types of WCF are highly practiced.

It is revealed that EFL Post-Basic teachers and supervisors have positive perceptions of the benefits of WCF. They strongly agreed that it is important to provide WCF on students' writing errors and it helps to improve the students' writing performance overall. It is also found that EFL teachers mostly practiced unfocused WCF technique) followed by indirect coded feedback. Indirect coded WCF technique through indicating (underlining/circling) errors and categorising them (with the help of a marking code), but without correcting them is the most practiced technique as 
perceived by the EFL supervisors. However, the least practiced technique is the focused or selective WCF. The EFL teachers focus on providing WCF on language rather than on content and organisation. Asking students to write one draft and setting more writing practice tasks to students who have problems with writing are the most common follow-up methods used by EFL Post-Basic teachers. Teachers' perceptions regarding the focus of WCF and the follow-up methods support the supervisors' perceptions. Finally, it was found that there were no statistically significant differences between the perceptions of the two groups of participants (EFL teachers and supervisors) regarding teachers' practice of WCF.

The findings of this study have underlined the positive perceptions of EFL teachers toward the importance of providing WCF on students' written texts. It has been shown that teachers' WCF practices were influenced by their beliefs about the significance of correcting students' writing errors, so the results have demonstrated that the techniques, focus, and follow-up methods of WCF are well practiced by the respondents. This reflects the respondents' awareness of the importance of WCF, so they were careful to provide WCF to their students' written errors. It is also found that teachers' perceptions regarding the importance of WCF and the WCF practices corporate the supervisors' perceptions which indicates that EFL teachers reported their actual WCF practices.

Thus, the findings highlight the necessity for providing teachers with training on giving more effective WCF on students' writings. It also shed light on several areas regarding WCF that would be worth of in-depth investigation of teachers' actual WCF practices using the content analysis approach to analyse samples of students' writings and using classroom observations. The focus on the teachers' perceptions of their WCF practices raises the question of the students' preferences with regard to their teachers' WCF practices.

\section{Acknowledgements}

The authors would like to thank Sultan Qaboos University for providing supportive research facilities for researchers. Due thanks go to the Ministry of education for making conducting the study in the Omani public education possible.

\section{References}

Abdelraheem, A. \& Fyle, C. O. (2016). Omani students' perceptions of effectiveness of formative feedback. International Journal of Learning Management Systems, 4(1), 1-8.

Al Ajmi, A. A. S. (2015). The Effect of written corrective feedback on Omani students' accuracy in the use of English prepositions. Advances in Language and Literary Studies, 6(1), 61-71. https://doi.org/10.7575/aiac.alls.v.6n.1p.61

Al Bakri, S. (2015). Written corrective feedback: Teachers' beliefs, practices and challenges in an Omani context. Arab Journal of Applied Linguistics, 1(1), 44-73.

Al Hajri, F. \& Al-Mahrooqi, R. (2013). Student perceptions and preferences concerning instructors' corrective feedback. Asian EFL Journal, 70(2), 28-53.

Al Seyabi, F. \& Tuzlukova, V. (2014). Writing problems and strategies: An investigative study in the Omani school and university context. Asian Journal of Social Sciences \& Humanities, 3(4), 37-48.

Al Shahrani, A. \& Storch, N. (2014). Investigating teachers' written corrective feedback practices in a Saudi EFL context. Australian Review of Applied Linguistics, 37(2), 101-122. https://doi.org/10.1075/aral.37.2.02als

Al Shamsi, S. (2013). English language teachers' perceptions regarding providing corrective feedback on grade 4-8 students' writing in Al Ain Schools (Master's Thesis). United Arab Emirates University, UAE. Retrieved from https://www.adec.ac.ae/en/ResearchDevelopment/Researchers\%20Publications/English\%20Language\%20Teac hers\%E2\%80\%99\%20Perception\%20Regarding\%20.pdf

Alkhatib, N. (2015). Written corrective feedback at a Saudi University: English language teachers' beliefs, students' preferences, and teachers' practices (Doctoral dissertation). University of Essex, Essex.

Al-Said, M. F. (1996). Responses to learners' writing in EFL at Sultan Qaboos University: A case of teachers' and students' beliefs (Master's thesis). Sultan Qaboos University, Sultanate of Oman.

Al-Shabibi, N. S. (2008). Pupils' responses to teachers' writing feedback in a secondary school in Oman (Master's thesis). Sultan Qaboos University, Sultanate of Oman.

Amrhein, H. R. \& Nassaji, N. (2010). Written corrective feedback: What do students and teachers prefer and why? Canadian Journal of Applied Linguistics, 13(2), 95-127.

Anderson, J. (1976). Language, memory, and thought. Hillsdale, NJ: Lawrence Erlbaum. 
Anderson, J. (1983). The architecture of cognition. Cambridge, MA: Harvard University Press.

Anderson, J. (1993). Rules of the mind. Hillsdale, NJ: Lawrence Erlbaum.

Atmaca, Ç. (2016). Contrasting perceptions of students and teachers: written corrective feedback. Journal of Language and Linguistic Studies, 12(2), 166-182.

Baleghizadeh, S. \& Rezaei, s. (2010). Pre-service teacher cognition on corrective feedback: a case study. Journal of Technology \& Education, 4(4), 321-327.

Bitchener, J. (2008). Evidence in support of written corrective feedback. Journal of Second Language Writing, 17(2), 102-118. https://doi.org/10.1016/j.jslw.2007.11.004

Bitchener, J. and Knoch, U. (2008). The value of written corrective feedback for migrant and international students. Language Teaching Research, 12(3), 409-431. https://doi.org/10.1177/1362168808089924

Bitchener, J. \& Knoch, U. (2009). The value of a focused approach to written corrective feedback. ELT Journal, 63(3), 204-211. https://doi.org/10.1093/elt/ccn043

Bitchener, J. \& Knoch, U. (2010). Raising the linguistic accuracy level of advanced L2 writers with written corrective feedback. Journal of Second Language Writing, 19(4), 207-217. https://doi.org/10.1016/j.jslw.2010.10.002

Bitchener, J. \& Storch, N. (2016). Written Corrective Feedback for L2 Development. Bristol: Multilingual Matters. https://doi.org/10.21832/9781783095056

Burt, M. (1975). Error analysis in the adult EFL classroom. TESOL Quarterly, 9, 53-63. https://doi.org/10.2307/3586012

Chandler, J. (2003). The efficacy of various kinds of error feedback for improvement in the accuracy and fluency of L2 student writing. Journal of Second Language Writing, 12, 267-269. https://doi.org/10.1016/S1060-3743(03)00038-9

Dekeyser, R.M. (1998). Beyond focus on form: Cognitive perspectives on learning and practising second language grammar. In C. Doughty and J. Williams (Eds.), Focus on Form in Classroom Second Language Acquisition (42- 63). Cambridge: Cambridge University Press.

Eissa, A. \& Fares, A. (2010). Responding to students' writing in UAE government secondary schools: Teachers' attitudes and practices, and students' perceptions (Doctoral dissertation). American University of Sharjah, UAE.

Ellis, N.C. (2005). At the interface: How explicit knowledge affects implicit language learning. Studies in Second Language Acquisition, 27(2), 305-352. https://doi.org/10.1017/S027226310505014X

Ellis, R. (2008). The study of second language acquisition (2nd edn). New York: Oxford University Press.

Ellis, R. (2009). A typology of written corrective feedback types. ELT Journal, 63(2), 97-107. https://doi.org/10.1093/elt/ccn023

Ellis, R., Loewen, S. \& Erlam, R. (2005). Implicit and explicit corrective feedback and the acquisition of L2 grammar. Studies in Second Language Acquisition, 28(2), 339-368. https://doi.org/10.1017/S0272263106060141

Ellis, R., Sheen, Y., Murakami, M. \& Takashima, H. (2008). The effects of focused and unfocused written corrective feedback in an English as a foreign language context. System, 36(3), 353-371. https://doi.org/10.1016/j.system.2008.02.001

Erkkilä, M. (2013). Teacher written feedback: Teachers' perceptions of given feedback. Department of Languages English, University of Jyväskylä.

Farrokhi, F. (2012). The effects of direct written corrective feedback on improvement of grammatical accuracy of high-proficient L2 learners. World Journal of Education, 2(2), 49-57. https://doi.org/10.5430/wje.v2n2p49

Ferris, D. (2002). Treatment of error in second language student writing. Ann Arbor: The University of Michigan Press.

Ferris, D. R. (1999). The case for grammar correction in L2 writing classes: A response to Truscott (1996). Journal of Second Language Writing, 8(1), 1-11. https://doi.org/10.1016/S1060-3743(99)80110-6 
Ferris, D. R. (2006). Does error feedback help student writers? New evidence on the short- and long-term effects of written error correction. In K. Hyland \& F. Hyland (Eds.), Feedback in second language writing: Context and issues (pp.81-104). Cambridge: Cambridge University Press. https://doi.org/10.1017/CBO9781139524742.007

Ferris, D. R. \& Roberts, B. (2001). Error feedback in L2 writing classes: How explicit does it need to be? Journal of Second Language Writing, 10(3), 161-184. https://doi.org/10.1016/S1060-3743(01)00039-X

Ferris, D. R., Liu, H., Sinha, A. \& Senna, M. (2012). Written corrective feedback for individual L2 writers. Journal of Second Language Writing, 22, 307-329. https://doi.org/10.1016/j.jslw.2012.09.009

Frantzen, D. (1995). The effects of grammar supplementation on written accuracy in an intermediate Spanish content course. The Modern Language Journal, 79(3), 329-344. https://doi.org/10.1111/j.1540-4781.1995.tb01108.x

Ghani, M. \& Ahmad, S. (2016). Corrective feedback for young learners: A study of corrective feedback preferences and practices of Pakistani teachers at primary level. Journal of Educational Research, (2).

Goldstein, L. M. (2005). Teacher writing commentary. Ann Arbor: The University of Michigan Press.

Hamouda, A. (2011). A study of students and teachers' preferences and attitudes towards correction of classroom written errors in Saudi EFL context. English Language Teaching, 4(3), 128. https://doi.org/10.5539/elt.v4n3p128

Hendrickson, J. M. (1978). Error correction in foreign language teaching: Recent theory, research, and practice. Modern Language Journal, 62(8), 387-398. https://doi.org/10.1111/j.1540-4781.1978.tb02409.x

Hubais, A. \& Dumanig, F. (2014). Form and content feedbacks in foreign language writing: The case of Omani learners of English. language in India, 14(11), 3-16.

Hyland, K. (2003). Second language writing. Cambridge: Cambridge University Press. https://doi.org/10.1017/CBO9780511667251

Hyland, K. \& Hyland, F. (2006). Contexts and issues in feedback on L2 writing. Hyland, K. \& Hyland, F. (Eds.), Feedback in second language writing: contexts and issues, 1-19. New York: Cambridge University Press. https://doi.org/10.1017/CBO9781139524742

Keh, C. (1990). Feedback in the writing process: a model and methods for implementation. ELT Journal, 44, 294-304. https://doi.org/10.1093/elt/44.4.294

Knoch, U. (2011). Rating scales for diagnostic assessment of writing: What should they look like and where should the criteria come from? Assessing Writing, 16(2), 81-96. https://doi.org/10.1016/j.asw.2011.02.003

Ko, K. (2010). Perceptions of KFL/ESL teachers in North America regarding feedback on college student writing (Doctoral dissertation). The Ohio State University, Ohio.

Krashen, S. (1982). Principles and practice in second language acquisition. Oxford: Pergamon.

Lalande, J. F. (1982). Reducing composition errors: an experiment. Modern Language Journal, 66(2), 140-149. https://doi.org/10.1111/j.1540-4781.1982.tb06973.x

Lee, I. (1997). ESL learners' performance in error correction in writing. Some implications for teaching. System, 25(4), 465-477. https://doi.org/10.1016/S0346-251X(97)00045-6

Lee, I. (2003). How do Hong Kong English teachers correct errors in student writing? Education Journal, 31(1), 153-169.

Lee, I. (2008). Understanding teachers' written feedback practices in Hong Kong secondary classrooms. Journal of Second Language Writing, 17(2), 69-85. https://doi.org/10.1016/j.jslw.2007.10.001

Lee, I. (2009). Ten mismatches between teachers' beliefs and written feedback practice. ELT Journal, 63(1), 13-22. https://doi.org/10.1093/elt/ccn010

Lindqvist, Å. (2012). The Use of Written Corrective Feedback. A Survey of Written Response from Teachers to ESL Students in English A-Course Upper Secondary School.

McLaughlin, B. (1978). The monitor model: Some methodological considerations. Language Learning, 28(2), 309-332. https://doi.org/10.1111/j.1467-1770.1978.tb00137.x

McLaughlin, B. (1980). Theory and research in second language learning: An emerging paradigm. Language Learning, 30(2), 331-350, https://doi.org/10.1111/j.1467-1770.1980.tb00322.x 
McLaughlin, B. (1987). Theories of second-language learning. London: Edward Arnold.

McLaughlin, B. (1990). Restructuring. Applied Linguistics, 11(2), 113-128. https://doi.org/10.1093/applin/11.2.113

Montgomery, J. \& Baker, W. (2007). Teacher-written feedback: Student perceptions, teacher self-assessment, and actual teacher performance. Journal of Second Language Writing, 16(2), 82-99. https://doi.org/10.1016/j.jslw.2007.04.002

Moradian, M. R., Miri, M. \& Hossein Nasab, M. (2017). Contribution of written languaging to enhancing the efficiency of written corrective feedback. International Journal of Applied Linguistics, 27(2), 406-426. https://doi.org/10.1111/ijal.12138

Phipps, S. \& Borg, S. (2009). Exploring tensions between teachers' grammar teaching beliefs and practices. System, 37(3), 380-390. https://doi.org/10.1016/j.system.2009.03.002s

Rajab, H., Khan, K. \& Elyas, T. (2016). A Case study of EFL teachers' perceptions and practices in written corrective feedback. International Journal of Applied Linguistics and English Literature, 5(1), 119-131. https://doi.org/10.7575/aiac.ijalel.v.5n.1p.119

Rajagopal, N. (2015). A teacher's written corrective feedback: beliefs and practices/Nilaasini a/p Rajagopal (Doctoral dissertation). University of Malaya, Kuala Lumpur, Malaysia.

Robb, T., Ross, S. \& Shortreed, I. (1986). Salience of feedback on error and its effect on EFL writing quality. TESOL Quarterly, 20(1), 83-93. https://doi.org/10.2307/3586390

Sheen, Y., Wright, D. \& Moldawa, A. (2009). Differential effects of focused and unfocused written correction on the accurate use of grammatical forms by adult ESL learners. System, 37(4), 556-569. https://doi.org/10.1016/j.system.2009.09.002

Srichanyachon, N. (2012). Teacher written feedback for L2 learners' writing development. Silpakorn University Journal of Social Sciences, Humanities, and Arts, 12(1), 7-17.

Stefanou, C. (2014). L2 article use for generic and specific plural reference: The role of written of, learner factors and awareness (Unpublished doctoral thesis). Lancaster University, UK.

Storch, N. \& Tapper, J. (2000). The focus of teacher and student concerns in discipline-specific writing by university students. Higher Education Research and Development, 19(3), 337-355. https://doi.org/10.1080/758484345

Thao, N. \& Anh, N. (2017). Error correction in teaching writing skill: From teacher's point of view to practice, a study at a Pedagogical University in Vietnam. Journal of Development Research, 1(1), 24-28. https://doi.org/10.28926/jdr.v1i1.13

Truscott, J. (1996). The case against grammar correction in L2 writing classes. Language Learning, 46(2), 327-369. https://doi.org/10.1111/j.1467-1770.1996.tb01238.x

Van Beuningen, C. (2010). Corrective feedback in L2 writing: theoretical perspectives, empirical insights, and future directions. International Journal of English Studies, (2), 1-27. https://doi.org/10.6018/ijes/2010/2/119171

Van Beuningen, C.G., De Jong, N.H. \& Kuiken, F. (2008). The effect of direct and indirect corrective feedback on L2 learners' written accuracy. ITL-Review of Applied Linguistics, 156, 279-296. https://doi.org/10.2143/ITL.156.0.2034439

Vygotsky, L.S. (1978). Mind in Society: The Development of Higher Psychological Processes. Cambridge, MA: Harvard University Press.

Wen, Y. (2013). Teacher written feedback on L2 student writings. Journal of Language Teaching and Research, 4(2), 427. https://doi.org/10.4304/jltr.4.2.427-431 